\title{
A refusal to (not) forget: (Post)Empire, transpolitics and locating diaspora in the anti- imperial consciousness of Howard Gayle
}

Daniel Burdsey ${ }^{1}$

Centre for Spatial, Environmental and Cultural Politics, University of Brighton, Brighton, UK

\section{ORCiD}

0000-0001-5803-8915

\begin{abstract}
In 2016, black former professional footballer, Howard Gayle, was awarded an MBE, in recognition of his work in anti-racist education. He rejected the accolade due to its colonial associations and the experiences of his African ancestors under the British Empire. This article analyses and theorises the geographical, cultural, political, historical and temporal contexts and consequences surrounding this refusal. While highlighting the fluid and reciprocal spatial and temporal positionalities that guide Gayle's articulations, it argues that it is essentially through and in the local spaces and places of his home city of Liverpool - a pivotal location in the historic international slave trade - that his anti-imperial consciousness is forged and enacted. The article addresses the possibilities that emerge from demands for social and reparative justice by public figures such as Gayle, in terms of decolonial thinking, anti-racist pedagogy and their status as a source rather than an object of knowledge.
\end{abstract}

\section{Article history}

Received 31 January 2019; Accepted 24 July 2019

\section{Key words}

Activism; Diaspora; Empire; Football; Place; Racism

\section{Prologue}

In 2016, former professional footballer, Howard Gayle, was awarded an MBE (Member of the Order of the British Empire). This title, part of an array of honours conferred annually by Queen Elizabeth II, recognises individuals who have undertaken outstanding work or

\footnotetext{
11D.C.Burdsey@brighton.ac.uk; @Centresecp.
} 
service in their communities. Thirty-six years previously, Gayle had made history by becoming the first black player to represent Liverpool Football Club; but it was for his actions in the more recent part of his life, as an ambassador for anti-racist organization Show Racism the Red Card, that he was acknowledged. Gayle publicly rejected the MBE, stating that, had he not done so, his "ancestors would be turning in their graves after how empire and colonialism had enslaved them" (cited in Guardian Sport 2016). "When you look at what the empire did to my family and our ancestors, it just doesn't bear credence”, he added, “I would always have felt uncomfortable writing those letters after my name” (Gayle 2016b).

\section{Overview and context}

Howard Gayle is not the first famous person to refuse a British Honour because of the awards' associations with the British Empire, namely the injurious colonial histories this signifies. $^{2}$ The circumstances and reasoning surrounding his rejection are nonetheless distinctive, for they show how the lived practices and experiential knowledges of (post)Empire, diaspora and racism can coalesce to form a radical, quotidian, anti-imperial political consciousness. This article argues that Gayle's decision and explanation offer important insights into the dialectical relationship between the structures, institutions and spaces of the racial state and forms of cultural resistance by racialised people. His statements, actions and political standpoint underscore the agentic potential of counter-hegemonic speech acts in a society that is claimed widely (yet erroneously) to be 'post-racial' and to have shaken off its colonial past, inside and outside of sport (Bhambra 2014, Gilroy 2004, Stoler 2016). ${ }^{3}$ In particular, they propound a well-defined, expansive black diasporic positionality: one that is both transhistorical and transnational in its orientation and appeals for decolonial, social and restorative justice. Gayle’s articulations are significant - not least in the realm of contemporary black sports activism - because they draw attention to, and enter into dialogue with, the racial 
violence of the (sometimes distant) past as well as the present; and they emphasize place, location and context, across multiple local and global configurations and scales.

Within the transnational positionality that Gayle embraces and advocates, diaspora as an everyday practice necessarily occurs - it is constructed, contemplated, lived and critiqued - in certain spaces and locations. While illuminating the various ways that Gayle speaks and acts inside and outside of history, and inside and outside of geographic spaces, this article argues that fundamentally it is through the connection and situation of these articulations to/in specific places and localities that the substance and power of his anti-imperial consciousness is realised. Put simply, it is through and in place that his own politics and activism - as a black Liverpudlian of African heritage - and the experiences of other black African diasporic citizens are animated and “made real”. Furthermore, it is via these connections between people and place that the complex diasporic histories of post-colonial port cities like Liverpool inexorably global but unapologetically local - can be understood. This article makes the case for foregrounding the specificities of space and place in Black Atlantic studies, arguing that alongside the transnational networks inherent to diasporic theorising, recognition of the local (and the various gradations of spatial analysis in between) must also be given analytical prominence.

The overarching aims of this article are twofold. First, it considers the particular geographical, cultural, political, historical and temporal contexts in which Gayle refused his MBE. These dynamics - many of which relate to his or others' experiences of racism, both in individual and institutional/systemic forms - not only provide essential background for understanding the motives for what he did and said; they also uncover and accentuate the sociopolitical significance and consequences of these actions. The factors outlined here reveal his 
use and frequent synthesis of macro global and micro local reference points - what Paul Silverstein (2004) refers to as 'transpolitics' - between Ghana and Sierra Leone (key sites in the slave trading activities of the British Empire and from where Gayle traces his ancestral roots), the city of Liverpool and the neighbourhood known as Liverpool 8 (where he was born, lived at various times throughout his life and now considers "home"). This exploration of aspects of Gayle’s biography demonstrates how his cultural reference points are situated both beyond and within the borders of the nation-state; and how they transcend historical epochs of past, present and future. In doing so, it illuminates the status, value and configurations of place, time and collective memory, across various scales, in his - and, in turn, this author's comprehension of Black Atlantic diasporic cultural politics.

Second, developing this discussion, the article proposes a conceptual argument regarding the fluid and reciprocal spatial and temporal positionalities that guide Gayle’s articulations. It contends that the specific place and time that he speaks from - Liverpool, or more precisely, Liverpool 8 - are inextricably grounded, historically and culturally, in the other places and times he speaks about; and reciprocally, his points of reference gain amplification and added meaning because of the location from which they are enunciated. This is shown to be an epistemological conjunction that comprises a fluid decentring and (re)centring of location - in geopolitical, social and enunciatory senses - within his vernacular. Yet, the argument concludes, it is ultimately through and in the spaces and places of the local - his home city of Liverpool - that Gayle makes sense of his life and those of other members of the black African diaspora, and in doing so is able to cultivate and locate his anti-imperial consciousness.

Black sports activism has re-emerged as a popular and pressing topic within the sociologies of race and sport. This is primarily a result of recent high-profile protests and 
embodied gestures by (primarily) African American elite sportswomen and sportsmen, under the rubric of the Black Lives Matter movement, against entrenched police brutality of black communities in the United States (Bryant 2018, Thangaraj 2017); but it also responds to the evolving activism of sportspeople elsewhere, such as footballers, such as Eniola Aluko, Danny Rose and Raheem Sterling in the UK. Indeed, sport has proved, once again, to be one of the principal sites for the symbolic refutation of authoritarian, racist politics across the Global North. Although US-based developments are undoubtedly momentous, prevailing academic analyses of black sports-based activism are problematic in that they occlude important issues and activities in other countries; and they frequently place key individuals, their actions and their historical eras in immutable, disconnected temporal silos (see e.g. Cooper et al 2019). Such an approach deters any consideration of the transhistorical and transnational positionality and potentiality found in the type of activist cultural politics embodied by Howard Gayle. By way of a rejoinder, this article draws attention to an example of sport-based activism informed by a black diasporic consciousness in which ontology and praxis transcend time and place. Distinct from calls for social change in Britain (and beyond) that rely on present-centred perspectives and from requests simply for recognition of past events, Gayle insists on political and public acknowledgment of how and where historically and globally iniquitous power relations, structures and institutions underpin the racial inequalities of modernity.

Gayle’s proclamations reside within a growing global movement demanding varied deeds of decolonial recognition, reparation or social justice: the remembrance of significant minority ethnic figures and/or historical achievements, injustices, tragedies and uprisings; the removal of statues and monuments of people associated with the slave trade, American Confederacy and other imperial projects; and the diversification of curricula in academic institutions (see e.g. Bhambra et al 2018, Torpey 2003, Upton 2015). Counter to these 
progressive politics, some prominent academics and race equality campaigners have talked down the deleterious effects of British colonialism (Bennett 2017). These debates have particular resonance in Howard Gayle’s home city of Liverpool (see next section). Moreover, the Crown and elements of the popular media have striven to erase the troubling historic imperial role of British royalty via the celebration and incorporation of the mixed race identity of the Duchess of Sussex, Meghan Markle. This collapsing of racialized time and space into a multicultural, post-imperial present absorbs race as a means of denying its structural effects and the adverse histories of the contemporary racialized communities it tries to valorise. In 2018, the British state’s imperial amnesia and its failure to bring about restorative justice were further evidenced when, under its stated "hostile environment" around immigration, the Conservative Party announced plans to deny free healthcare to some members of the post-war 'Windrush Generation’ of Caribbean migrants, and to even deport a number of settled British citizens (de Noronha 2019).

\section{Figure of 8: playing and speaking in, from and beyond Liverpool 8}

In 1980, three years after signing as a professional footballer, Howard Gayle became the first black player to represent Liverpool FC, one of the city of Liverpool's two First Division teams. He made four further appearances for the club’s first team (scoring one goal) before continuing his career at other clubs in England and the United States. ${ }^{4}$

By exploring aspects of Gayle's life story, the factors which underpin and influence his modern day anti-imperial consciousness become apparent. Critically, his experiences of, and standpoints on, the racial state, (post)Empire, citizenship and diaspora are revealed eruditely and powerfully through his contemplations on locality and place, and via his appreciation of transpolitical connections and scale. His anti-imperial consciousness is moulded by a critical 
black politics in and of Liverpool, notably the local, national and global routes, struggles and resistances that emanate from, and converge on, the city.

Gayle was born in 1958 in a south Liverpool neighbourhood known, after its postal code, as Liverpool 8. Gayle’s father, Purcell, had been born in Sierra Leone, and his mother, Alice, in Liverpool of mixed black Ghanaian and white heritage. Gayle notes that, like the descendants of millions of enslaved Africans, his surname stems from an historic plantation owner in Sierra Leone (Black Lives Matter Worldwide 2018). Even when referencing the period before his birth, one gets a sense of the importance of local as well as global places in his anti-imperial consciousness. In addition, while Gayle identifies distinctly with a racial and political "black" identity, his hybrid heritage underpins elements of his worldview and guides how he understands diaspora as experienced in local, national and international contexts, manifestations and scales. He speaks about the ostracism his white grandmother experienced after marrying a black man (Gayle 2017), exposing the incorrigible demonization of inter-racial marriage and the pathologisation of mixed-race children in Liverpool (Christian 1998, 2008; Small 1991). Alongside the African antecedents of his family's history, he describes his mother working in Kirkby, a 'new town' developed near Liverpool in the 1950s to deal with the city’s housing overspill. Gayle notes that "our family has deep, deep roots in Africa but also within this country” (cited in Black Lives Matter Worldwide 2018).

Gayle’s family were relocated by Liverpool Housing Corporation soon after his birth, and he spent his formative years on the predominantly white housing estate of Norris Green in Liverpool's north end. Among the many challenges that arose after the move were Gayle's contrasting feelings of racialised inclusion and exclusion in the two areas he had lived. The black population in Liverpool 8 has been much larger than in any other part of the city in the 
post-war era, succeeding the area around Pitt Street (nearer the docks in the southern part of the city) as the spatial focus of black community and cultural life (Brown 2005, Christian 1998). ${ }^{5}$ Norris Green “wasn’t the same as the south end”, he writes (Gayle 2016a: 13), meaning that he was not "brought up around people of my own kind" (cited in Through Paisley Eyes 2018). Liverpool 8 hence became an important space for Gayle as a young man, especially its cultural institutions and social activities. Underlining the significance of time and place in formations of racialized resistance and resilience, he states, “All week, I'd look forward to going back to Liverpool 8” because "to me it was a sanctuary from Norris Green where outsiders were distrusted” (Gayle 2016a: 14).

Liverpool's racialised history - namely its pivotal role in the forced movement and annihilation of black Africans through the international slave trade (see next section) resounds in particular public and private spaces, institutions and memories throughout the city: in statues, street names, former residences of slave merchants, financial institutions, and other colonial-era buildings. ${ }^{6}$ Alongside his recognition of these sites, Gayle’s consideration of the city’s historical racialised spaces and their connections to Empire includes a more organic, counter-hegemonic take, focusing on the cultural as much as the political and economic. Throughout his memoir, Liverpool 8's social and leisure spaces are recurrent anchors of Empire, diaspora and multiculture: Mr. Peewee’s barber shop on Granby Street; playing for The Timepiece football team in Sefton Park, a side that "represented the black community in L[iverpool] 8” (Gayle 2016a: 62); and night clubs representing a range of communities, such as the Yoruba, Nigerian, Sierra Leone, Ebo, Somali, Caribbean and Alahram venues (ibid.: 17, 59). While he was growing up, “Granby Street mimicked a bazaar with its Muslim butchers and Arab, Pakistani and Bangladeshi mini-markets selling exotic fruits, unusual vegetables and 
red-hot spices”. "All of them”, he concludes, “offered something towards the identity of [the area]" (ibid.: 17).

Gayle’s biography and the positionality that emerges from his hybrid heritage show that it was not just his experiences of key black spaces and institutions that provided his socialisation and nurtured his anti-imperial critique; it was also his relationships with (real and imagined) white ones, especially those that were representative of the (racial) state, such as schools, the criminal justice system and housing corporations. This illustrates instructively how a black diasporic consciousness involves the engagement, juxtaposition and negotiation with/of whiteness as well as with other members of one’s ethnic community. Although Gayle recalls difficult times in Norris Green - experiences of racism, crime, abuse and the death of his mother - it is "the place that probably had the most profound impact on my life" (Gayle 2016a: 12), and "had it not been for my experiences there, though, I'm not sure whether I'd have made it as far as I did” (ibid.: 131).

A central, recurrent theme in Gayle's memoir is his experiences of racism. "For me, racism was the norm - the routine”, he states (Gayle 2016a: 93), and his encounters in football mirror those in other predominantly-white institutions during his and others' lives. Throughout the twentieth century, Liverpool-born Blacks encountered what Mark Christian, the leading academic voice on black Liverpool, describes as a "catalogue of horrific racism” (Christian 1998: 295). This includes a series of anti-black riots, such as those in 1919 when Charles Wootton, a Bermudan seaman, was killed after being chased by a mob into the River Mersey and stoned to death (Christian 1998) ${ }^{7}$; the injurious repercussions of Muriel E. Fletcher's pathological studies of inter-racial marriage and mixed-race children in the city (Christian 2008); the historical “de facto ghettoization” of Liverpool 8 (Christian 1998: 301); and the 
exclusion of people of colour from numerous private and public spaces and institutions - not least the stadia of the city’s professional football clubs, Everton and Liverpool (Burdsey 2018, Christian 2011, Hill 1989). The extent of these problems was highlighted in a study sponsored by Liverpool City Council in the 1980s which described the city as “uniquely racist” (cited in Zack-Williams 1997: 529).

Throughout his time at Liverpool FC, Gayle was subjected to racially abusive comments, “jokes” and behaviours from some team-mates. For instance, as Gayle was about to start a sprint drill during one training session, the white South African-born goalkeeper, Bruce Grobbelaar, announced, “Ready, steady, pick up your lips. Run” (cited in Herbert 2016). Gayle tells another story about a club Christmas party, when a stripper covered her chest in talcum powder and rubbed her breasts against his face, leaving a white covering on his skin. The compere, Roy Chubby Brown, provided the punchline: "Try and walk through Toxteth now" (Gayle 2016a). By using the designation 'Toxteth', rather than Liverpool 8, the comic reproduced racialized power and the politics of location, time, enunciation and mis/recognition in this local context (Christian 1998, Cornelius 1982, Small 1991, Tafari 1989). Popular discourses tend to conflate Toxteth and Liverpool 8 geographically and descriptively (usually preferring the former moniker), but Toxteth is one part of Liverpool 8 and somewhat separate from the original black settlements in the area. Gayle (2016a: 13) is again cognisant of the nuances of race and locality: "For the black community, Toxteth was always Park Road - a white area”. While political and hegemonic media portrayals of the 1981 'riots' in the area placed and criminalised Liverpool's black community in Toxteth, for those on the 'other side' of history it was different: these were ‘uprisings’ in/from Liverpool 8 (Frost and Phillips 2011). 
Gayle had returned to live in Liverpool 8 by the time he signed a professional contract with Liverpool FC in the late 1970s. This was a matter of great consternation for his employers. Reproducing spatialized racial stereotypes about blackness and delinquent behaviours, the club - especially manager Bob Paisley - tried to restrict his relationships with the area's people and places, and encouraged him to move elsewhere (Gayle 2016a). Regarding Paisley, Gayle says that:

I think he was concerned by influences and the events that were going on down there. But this was where my people were, where my family lived. I was conscious that I should never ever forget where I came from. It was important for me to show there were good things that came out of Liverpool 8, despite all the propaganda (cited in Kay 2019).

It is in the context of the Liverpool 8 uprisings that time becomes a lens through which Gayle talks about race and place as well: "I look back at 1981 [the year of the uprisings and in which he played in a European Cup semi-final] as the defining year of my life” (Gayle 2016a: 125). Then, adopting a specific racialised and localised standpoint epistemology, he asserts that "only those directly affected really appreciated how [the unrest] was the inevitable consequence of a history of police harassment, intimidation and brutality inflicted on Liverpool 8's black community” (ibid.: 123).

Epitomising a tradition of cultural and political resistance in the Liverpool 8 area, Gayle steadfastly stood up to racist bullying throughout his career. Encounters with white Liverpool team-mate, Tommy Smith, were especially difficult. In describing his response to Smith's racism, the racialisation of place is again present with Smith's background in the Scotland Road 
area - a centre of white working-class life in north Liverpool - offered as context (Gayle 2016a: 96). Like many other black players of his generation, Gayle’s refusal to accept racism frequently led to accusations that he had a 'chip on his shoulder'. This rhetoric was used in football (and other institutions) to deny the presence of structural inequality and discrimination, thereby individualising racism and claiming that legitimate responses were in fact pathological gripes. Black players were seen both to disingenuously invoke race as a characteristic of their experiences and to use it as a barrier to acknowledging alternative, deracialized interpretations of their treatment. Gayle refused to acquiesce with dominant discourses, maintaining that, "I didn’t have a chip on my shoulder, I just wasn’t taking that sort of crap” (Gayle 2017). He adds that, "I had a responsibility not only to myself but to my culture because [black players] were going to follow in my footsteps like [future Liverpool player, John] Barnes”, and declares that, “ultimately before I was a footballer, before I was Liverpool fan, I was a black man and I wasn’t prepared to sacrifice who I was to be a football player” (cited in Morgan 2018). Gayle feels that his proclivity to talk candidly about his experiences of discrimination have rendered him a 'risky body', deterring Liverpool FC from involving him in their current commercial activities (Gayle 2017).

Gayle’s diasporic politics are not only directed towards the past. Today he forges panethnic and pan-religious African diasporic solidarities, empathising with the experiences of Liverpool FC’s Muslim players - including Naby Keïta, Sadio Mané and Mohamed Salah and arguing that racism and Islamophobia are concealed by claims of 'post-racial', meritocratic sporting structures (Morgan 2018). Once more his considerations of race, ethnicity and inclusion in football have a local orientation, noting - before the breakthrough of current star full-back Trent Alexander-Arnold - the limited Liverpool FC careers of black/mixed-race players Tony Warner, Jon Otsemobor and Lee Peltier. Gayle (2016a: 211) questions, “If I was 
a groundbreaker, why hasn't there been more black players in the team after me: boys who emerged from the streets of Liverpool?”.

\section{Looking back to move forward: Empire, the past-as-present and the politics of remembering}

Howard Gayle’s encounters with the private and public institutions of the racial state are evidently grounded in place; and he situates them as consequences of the British Empire and slave trade too. This orientation of his ancestry and his current past-as-present political ontology highlight how stories, struggles and memories of subjugation are brought to bear in the modern diasporic condition (McKittrick 2002, Sharpe 2016, Zeleza 2005). Liverpool’s racialised history commences with its role in the British Empire, explicitly its status from the early eighteenth century as "a seaport of incalculable national and global significance” in the slave trade (Brown 2005: 4). Five-eighths of the English, and three-eighths of the European, slaving fleets operated out of Liverpool, respectively. In short, the city's status and affluence during the Industrial Revolution derived from its role in the forced deportation of millions of Africans from their homes as chattel slaves (Zack-Williams 1997). Thus, as Christian (1998: 303-4) argues, that “the city's deep-rooted links with the slave trade make it an obvious candidate for the analysis of globalized and historical racist practices toward peoples of African descent (in all their various hues and characteristics)”.

Together with its prominence as the first established black community in the UK (Small 1991), Liverpool also necessitates a distinctive take on the spaces and times of the British Empire. It requires a rethinking of historic Atlantic passages and the dominant (post-)colonial "Windrush" discourse of black migration as emanating from the Caribbean and after the Second World War (Belchem 2014; see Olusoga 2016 on the multiple roots and routes of Britain’s early black communities). Unlike black communities in other British metropolises, 
Liverpool's black population throughout the twentieth century traced its origins primarily to West African countries; and to multiple generations of settlers dating back to the 1700 s, including free and enslaved people, and then later factory workers, seamen, soldiers and students (Small 1991). Such associations and movements oscillate on a north-south axis, highlighting alternative trajectories to the latitudinal inclinations found in customary conceptualizations of black transatlanticity.

Alongside the specific Liverpool places that Gayle mentions, he locates the city as a seaport in a broader geographical and historical nexus of colonialism and im/migration. Typifying the city's external-facing outlook, he proposes that it "has more in common with Marseilles, Naples or Dublin than it does with Birmingham, Sheffield or Leeds” (Gayle 2016a: 17). Instead of beginning his autobiography with a customary sporting anecdote, the book commences with the historical experiences of enslaved Africans in Sierra Leone - specifically the British slave trading post of Bunce Island - together with remarks on Liverpool's pivotal contribution to these atrocities (Gayle 2016a). ${ }^{8}$ Gayle is mindful of the city’s prosperity from slavery, together with the repercussions that remain today, structurally and for him personally. He states that "what happened [in Sierra Leone] centuries ago impacted especially upon my early life and continues to do so today” (Gayle 2016a: 1).

Gayle references social and political factors inside and outside of the contemporary juncture, and places them in reciprocal political dialogue, making connections between (anti)imperial politics "then” and "now”. Citing recent armed conflicts in Iraq and Syria, and the neo-imperial politics of US President Donald Trump, he asserts that: 
Britain hasn't really learned the lessons of its past. We are always in conflict with other nations, always making the same mistakes. I'm making my point now, but in 100 years will there be some Arab man or woman refusing an honour because of what we have done to Iraq or Syria? (cited in Guardian 2016b).

His standpoint encompasses a discernible historical awareness and his pedagogic intervention foregrounds temporality in (re)considerations of the colonial contracts between imperial powers and their territories (Mills 1997). Gayle demonstrates evocatively the multitude forms and methods through which the racialised past lingers in the current time for people of colour - what Aníbal Quijano (2007) calls coloniality, Ann Laura Stoler describes as the duress of a colonial presence (as well as present), and Christina Sharpe (2016: 13) refers to as being in the wake of a "past not yet past”. For Gayle, slavery and colonialism are brought into the present, into life, through the connotations of the MBE, representing a "past which is imagined to be over but persists, reactivates, and recurs in transfigured forms” (Stoler 2016: 33). He states that "parts of colonialism are still relevant today... when I look at the past and I when I look at the future I can’t see any change” (Gayle 2017).

Gayle's activism revolves, therefore, around not only a politics of recognition, but also one of remembering, and so encompasses a praxis of change through calls for decolonial, social and reparative justice. He refuses to accept how slavery is (not) taught, remembered and memorialized, by the state and by the communities affected by the activities and repercussions of Empire. Discussing his rebuttal of the MBE, he states that: 
As I see it, this is about the past, but also about the present, because I don't think there has ever been any recognition of what was done in Britain's past. The education system told me nothing but lies about Africa...If there had been some proper recognition here of the way the empire treated Africa and Africans, I might have looked at this nomination differently (Gayle 2016b).

With appreciation of race, migration, time, and the unequal ways in which different global bodies are valued and their deaths memorialized, he juxtaposes this scenario against the state's remembrance of deceased twentieth century service personnel:

Every year in this country we remember the heroic efforts of people who gave their life for this country within the First and the Second World Wars. But as descendants of Africa we're not allowed to remember or to bring up the subject of the slave trade (cited in Black Lives Matter Worldwide 2018).

This disparity is embedded similarly in reactions to his MBE refusal: "A lot of people understood my reasons”, he remarks, but "others were saying, 'Who the hell does he think he is? He should be grateful that he’s lucky enough to live here among us’” (cited in Kay 2019). Gayle challenges the epistemology of what is permitted to be said about British imperialism, who is allowed to talk about it and on which terms. He calls for a more radical reading of time, space and Empire than is found in many institutional acts and places of remembrance. He does not capitulate to the belief that 'official' recognition of past atrocities can meaningfully decouple and decolonize the lingering linkages between European colonial history and popular collective memory (Sharpe 2016, Yeğenoğlu 2017). Gayle embodies how remembering is a political act, as well as a personal one: what is (allowed to be) remembered and forgotten is 
contested and can be harnessed as resistance to power structures (Ackah 1997, Hesse 2002, Moody 2014, Schwarz 2011, Small 2018). In short, he demonstrates an individual refusal to forget the horrific subjugation of African people under the terror of the British Empire and to accept the racism of the modern racial state; while simultaneously he uses an institutional refusal of a British Honour to not let the state do the same.

\section{'Children of the ghetto': ${ }^{9}$ de/re/centring place, transpolitics and epistemic location}

With an understanding of the fluid nature of racialized identity politics, the mutability and un/fixed nature of diasporic places, and the nuances of spatial scale, Gayle articulates both a figurative and tangible decentring and (re)centring of place. He forges broad historical, cultural and political connections outside, between and across particular locales within Africa and its diaspora - an approach that decentres specific places and understands them instead within a wider global configuration of people, spatiality and power. Indeed, at one level, Gayle’s historical references to Africa, Empire and slavery speak persuasively without making connections to, or elucidating the significance of, his home city. Yet Gayle's speech acts concurrently (re)centre and give primacy to specific places and scales of reference, both spatial and temporal. In this case, the spaces and places (both lived and imagined) of Liverpool - the

cultural institutions and leisure spaces of Liverpool 8, Norris Green, Liverpool FC’s Anfield stadium and Melwood training ground - together with the slave colonies of Ghana and Sierra Leone, and the transatlantic slave ship; and the time periods from the historic international slave trade to the 1980s in which the Liverpool 8 uprising took place, and when the city in general was under attack from Margaret Thatcher’s Conservative government.

Paul Gilroy (1993) challenges the reliance on nationalist perspectives and the primacy of the nation-state in understanding how modern black cultures exist and resist, and highlights 
inter- and transnational spaces and processes of black political organization and responses to racial violence. Although Gayle’s specific recognition of place(s) directs attention towards geopolitical extremities - global and local - the nation-state is never absent from his actions or the ontology of his anti-imperial consciousness. Britain was responsible for the global subjugation and terror to which he speaks, and should be held accountable for a widespread political and public failure to remember, repair and repay. Gayle's act of refusal is inexorably a challenge to the governance and status of nation and nationalism, manifest in the institutions of the (racial) state, including the government, the Royal Family and education system.

The overarching contention of this article is that the location and time that Howard Gayle speaks from, and the places and periods he speaks about, are mutually reinforcing. Specifically, it has argued that it is through the connection and situation of these articulations to/in specific places and localities that the significance and power of his anti-imperial, diasporic consciousness is realised. In short, these are the sites which enable and permit him (and others) to make (sense of) his refusal. The power of this positionality comprises what Ramón Grosfoguel (2011) refers to as one’s ‘locus of enunciation’. This is “the geo-political and bodypolitical location of the subject that speaks" (ibid.: 4). Caution is required to not suggest that Gayle's perspective is an inevitable or immutable consequence of his particular racialized identity and biography or place of residence. The ontological 'fixing' of race to particular bodies, communities and spaces in acts of resistance can reproduce the orthodoxies it seeks to challenge (Nayak 2010); and any intimation that being born in a place makes someone belong more than a recent arrival is analytically unconvincing and politically problematic. Moreover, as Grosfoguel argues, one's epistemic location is not synonymous with their social location. While an individual may be subjugated due to the configuration of power relations, they will not automatically or necessarily think and speak from that marginalized epistemic location, for 
the hegemonic imperial system has cajoled some oppressed peoples into endorsing their discourses. Yet, in this instance, Gayle’s epistemic and enunciatory location align with his social - and, critically, also his geographical - location. This commingling of identity, discourse, space, time and power unravels the magnitude of what Howard Gayle did and said. It illuminates the role of historical context and collective memory in diasporic formations; it emphasizes the role of scale, place and location (in all senses) in the vernacularism of the marginalized; and, following Katherine McKittrick (2002: 28), it asks us to "stretch and reconfigure the meaning of unsatisfactory, racial, geographical boundaries”.

Ultimately, Gayle’s transpolitical stance can be summed up in the following position: “Sierra Leone, indeed, is not a place I consider to be home”, he writes, "but it is the place where my family’s story begins” (Gayle 2016a: 1). Rather, Liverpool 8 is “the area for me that still represents home” (ibid.: 12). The outcome for his identity then is clear, with history, place and scale present as always: “I’m an African...I'm an African Scouser” (Gayle 2017). ${ }^{10}$ Gayle is a citizen of the world. He is a member of the black African diaspora. He is a resident of Liverpool 8.

\section{Final remarks: lessons from Howard Gayle’s decolonial epistemology}

This article has presented a case study of the activism of Howard Gayle: erstwhile professional footballer, and current anti-racist campaigner and social inclusion coach. It has analysed the geographical, historical and cultural connections between West African countries, Liverpool and Liverpool 8 that illuminate the context and symbolism of his actions in turning down an MBE. It has established that his anti-imperial consciousness is both spatially and historically attentive and fluid with regard to race, racialization and the collective memory of 
the black African diaspora; but that, essentially, it is forged, enacted and remembered in and through place.

Gayle’s 'bottom-up’ approach towards foregrounding and democratising the collective memory of Empire, slavery and colonialism, based on the experiences of those who have been directly affected by these events, points towards the possibility of a timely and powerful alternative praxis. He speaks presciently and potently on a number of topics: from the coloniality of his and others' lived experiences to contemporary global imperial politics. In short, he draws attention to what Gayatri Gopinath (2018: 129) refers to as "the impossibility of normativity for racialized subjects marked by histories of violent dispossession”. He does so with/from what can be considered a decolonial epistemology (Ndhlovu 2016). This represents a perspective that "questions the monopoly and universalizing tendencies of epistemologies from the Global North, and calls for the recognition and mainstreaming of other knowledges and ways of engaging with knowledges” (ibid.: 36). Gayle repudiates dominant, monolithic Western epistemes that demand the hemispheric binary as the crucial element of knowing (see Bhambra 2018, Connell 2018, Lowe 2015, Mignolo 2011, Santos 2014, Savransky 2017). ${ }^{11}$ He makes this intellectual ground murky, and collapses “from” and "about” as co-constitutive elements of power, learning and belonging.

The import and influence of Gayle's actions arguably lie, then, beyond their substantive content; they derive similarly from their epistemological foundations and outcomes. Not only do these confront dominant, colonising perspectives and orthodoxies, but they also navigate us towards an alternative interpretative position from where we can think differently about (post)Empire and black diasporic (sporting) lives. The implications for scholars are especially pronounced, for Gayle's articulations (and those of others who speak forms of truth to 
racialised power) can act as a catalyst to (re)consider the construction and location of the knowledge that is valued and privileged within the study of race and sport. This would surely be the type of outcome advocated by Gayle: a replacement of ethnocentric educational curricula and a challenge to racialised institutional amnesia.

The power and reach of subversive vernacular, philosophical and political speech acts that emerge from the world of sport - especially from athletes of colour - are well recognised (Carrington 2010, Farred 2003, Turner 2018). What would happen though if we were to attribute a professional sportsperson the status of someone we can learn from, rather than an object of scholarly curiosity and critique as is routinely the case? This is a matter, as Faye Harrison (2016: 162) advocates, of "perform[ing] an ethic of inquiry that induces less hierarchical relations of knowledge production with the building of theory integral to it”. Our task is to consider how we might harness, as pedagogy, the symbolism of such a vernacular understanding of the black experience: that speaks about, from and beyond sport; that transcends spatial and temporal frames of reference; and is attentive to knowledges and worldviews that trace their origins from outside the northern hemisphere’s canon.

The need for approaches that decolonize knowledge, decentre Northern hegemonies, and engage with alternative, subaltern ways of thinking about the racialized inequalities inherent to modern sport is more pressing than ever. Apropos the social sciences more generally, what we can learn and what we need to know about the sociology of sport and race extends well beyond forms of knowledge created in, and prioritised and circulated by, the academic institutions of the Global North. We must broaden the parameters of whose knowledge and which ways of thinking are valued. As this article has shown through an exploration of the activism and anti- 
imperial consciousness of Howard Gayle, by doing so our capacity to think, write and teach expansively and, not least, inclusively and progressively is increased considerably.

\section{Acknowledgements}

I am grateful to Stan Thangaraj, Thomas Carter, and the journal's editors and reviewers for their constructive and supportive feedback on earlier drafts of this article. I also thank Mark Christian for teaching me so much about the Black Liverpool experience. Any errors are, of course, mine.

\section{Notes}

1 At the end of his memoir, Gayle briefly outlines two subsidiary reasons for his decision to refuse the MBE. Both relate to the institutions of the British state. First, his critique of the establishment's response to the 1989 Hillsborough stadium disaster in which 96 Liverpool FC supporters were unlawfully killed. Second, the sexual abuse he experienced as a young man from a school sports teacher (reported earlier in the book) (Gayle 2016a: 214).

2 Gayle's rebuttal was preceded by Rastafarian poet and activist Benjamin Zephaniah (in 2003), British Asian musician Nitin Sawhney (in 2007) and black hip-hop artist Jonzi D (in 2011). See Harper (2017) for a discussion on Zephaniah.

3 This article uses secondary data, comprising a range of narratives articulated by Howard Gayle, all which are in the public domain: sections of his written memoir (Gayle 2016a), print media and online interviews (various sources; see bibliography), and a public talk in Liverpool in October 2017 (Gayle 2017).

4 Gayle was the second Liverpool-Born Black player to represent one of the city's professional clubs, following fellow Liverpool 8 resident, Cliff Marshall, who played for Everton FC's first team in 1975. A decade before that, Mike Trebilcock, a Cornishman of "black mixed heritage" (Christian 2011: 137), also represented Everton. It is also historically noteworthy that it was a player of African heritage - the Gold Coast (Ghana) born, Arthur Wharton - who became the first black professional in England, nearly 100 years before Gayle’s debut. Like Gayle, his career was dogged by racism, inside and outside the game.

5 The demographics of Liverpool 8 have shifted in the years since Gayle's young adulthood, but over half of the residents in the electoral ward in which the neighbourhood is located remain from a minority ethnic background (Uduku 2003). This compares to less than 14 per cent of the city as a whole (Liverpool City Council 2016; see also Belchem 2014, Brown 2005, Connolly et al 1992).

6 For instance, a student-led campaign was launched in 2017 at the University of Liverpool to remove the name of William Gladstone from one of the institution's buildings. Gladstone, 
a nineteenth century British Prime Minister, had fought for reparations for slave owners (including his own father) (Perraudin 2017).

7 Wootton was memorialized in the name of a pioneering educational institution in Liverpool 8 between the 1970s and 1990s.

8 In 1999 the city of Liverpool formally apologized to its black communities for its role in the slave trade and subsequent years of institutional racism. Liverpool has an International Slavery Museum but no permanent public memorial (Brown 2005, Christian 2008, Haggerty et al 2008, Moody 2014, Steele 2008).

9 'Children of the Ghetto' is a song written in 1977 by Liverpool 8 band, The Real Thing, and recorded as part of the 'Liverpool 8 Medley' on their LP 4 from 8.

10 'Scouser' is a colloquial term for a person from Liverpool.

11 See Tuck and Yang (2012) for a critique of discourses of decoloniality in academic writing.

\section{References}

Ackah, William. 1997. "Organisation and identity in local, national and global context.” In Black Organisation and Identity in Liverpool: A Local, National and Global Perspective, edited by William Ackah and Mark Christian. Liverpool: Charles Wootton College Press.

Belchem, John. 2014. Before the Windrush: Race Relations in Twentieth-century Liverpool. Liverpool: Liverpool University Press.

Bennett, Rosemary. 2017. “Colonialism not all bad, says equality campaigner Trevor Phillips.” Times, December 27. Accessed $11 \quad$ June 2018. https://www.thetimes.co.uk/article/colonialism-not-all-bad-says-equality-campaignertrevor-phillips-zvmbzdcst

Bhambra, Gurminder, K. 2014. Connected Sociologies. London: Bloomsbury.

Bhambra, Gurminder, K., Gebrial, Dalia, and Nişancioğlu, Kerem. Eds. 2018. Decolonizing the University. London: Pluto Press.

Black Lives Matter Worldwide. 2018. "Howard Gayle turns down MBE: 'descendants of Africa are not allowed to bring up slavery'." Accessed 14 June 2018. https://www.youtube.com/watch?v=te1y L279oyU

Brown, Jacqueline Nassy. 2005. Dropping Anchor, Setting Sail: Geographies of Race in Black Liverpool. Princeton, NJ: Princeton University Press.

Bryant, Howard. 2018. The Heritage: Black Athletes, a Divided America, and the Politics of Patriotism. Boston: Beacon Press. 
Burdsey, Daniel. 2018. “Soccer, race and empire: locating the past in the present.” Engaging Sports, $\quad$ https://thesocietypages.org/engagingsports/2018/12/03/soccer-race-andpostempire-locating-the-past-in-the-present/

Carrington, Ben. 2010. Race, Sport and Politics: the Sporting Black Diaspora. London: Sage.

Christian, Mark. 1998. "An African-centered approach to the Black British experience: with special reference to Liverpool.” Journal of Black Studies 28 (3): 291-308.

---- 2008. “The Fletcher Report 1930: a historical case study of contested Black mixed heritage Britishness.” Journal of Historical Sociology 21 (2-3): 213-241.

---- 2011. 'Mixing up the game: social and historical contours of black mixed heritage players in British football.” In Race, Ethnicity and Football: Persisting Debates and Emergent Issues, edited by Daniel Burdsey. Abingdon: Routledge.

Connell, Raewyn. 2018. “Decolonizing sociology.” Contemporary Sociology 47 (4): 399-407.

Connolly, Michelle, Roberts, Kenneth, Ben-Tovim, Gideon, and Torkington, Protasia. 1992. Black Youth in Liverpool. Netherlands: Giordiano Bruno Culemborg.

Cooper, Joseph, Macaulay, Charles, and Rodriquez, Saturnino. 2019. "Race and resistance: a typology of African American sport activism.” International Review for the Sociology of Sport, 54 (2): 151-181.

Cornelius, John. 1982. Liverpool 8. London: John Murray.

de Noronha, Luke. 2019. "Deportation, racism and multi-status Britain: immigration control and the production of race in the present." Ethnic and Racial Studies, DOI: $10.1080 / 01419870.2019 .1585559$

Farred, Grant. 2003. What's My Name? Black Vernacular Intellectuals. Minneapolis: University of Minnesota Press.

Frost, Diane and Phillips, Richard. Eds. 2011. Liverpool '81: Remembering the Riots. Liverpool: Liverpool University Press.

Gayle, Howard. 2016a. 61 Minutes in Munich: The Story of Liverpool FC's First Black Footballer. Liverpool: deCoubertin Books.

---- 2016b. "Why I showed the red card to an MBE.” Guardian, August 15. Accessed 18 June 2018. https://www.theguardian.com/commentisfree/2016/aug/15/howard-gayle-mbeliverpool-first-black-footballer

---- 2017. Public talk for Smithdown Litfest, Ullet Road Unitarian Church, Liverpool, 2 October 2017.

Gilroy, Paul. 1993. The Black Atlantic: Modernity and Double Consciousness. London: Verso.

---- 2004. After Empire: Melancholia or Convivial Culture? London: Routledge. 
Gopinath, Gayatri. 2018. Unruly Visions: The Aesthetic Practices of Queer Diaspora. Durham, NC: Duke University Press.

Grosfoguel, Ramón. 2011. “Decolonizing post-colonial studies and paradigms of politicaleconomy: transmodernity, decolonial thinking, and global coloniality.” Transmodernity: Journal of Peripheral Cultural Production of the Luso-Hispanic World 1 (1): 1-37.

Guardian Sport. 2016. "Howard Gayle turns down MBE because it would be 'betrayal of Africans'," Guardian, August 11. Accessed 18 June 2018. https://www.theguardian.com/football/2016/aug/11/howard-gayle-mbe-betrayalafricans-liverpool

Haggerty, Sheryllynne, Webster, Anthony, and White, Nicholas. Eds. 2008. The Empire in One City? Liverpool's Inconvenient Imperial Past. Manchester: Manchester University Press.

Harper, Tobias. 2017. “The Order of the British Empire after the British Empire.” Canadian Journal of History 52 (3): 509-532.

Harrison, Faye, V. 2016. “Theorizing in ex-centric sites.” Anthropological Theory 16 (2-3): 160-176.

Herbert, Ian. 2016. "Howard Gayle: 'If they'd thrown that banana at me at Goodison Park, I'd have thrown it straight back'." Independent, October 5. Accessed 14 June 2018. https://www.independent.co.uk/sport/football/news-and-comment/howard-gayleliverpool-john-barnes-1980s-racism-anfield-first-black-liverpool-player-a7346961.html

Hesse, Barnor. 2002. "Forgotten like a bad dream: Atlantic slavery and the ethics of postcolonial memory.” In Relocating Postcolonialism, edited by David Theo Goldberg and Ato Quayson. Oxford: Blackwell.

Hill, Dave. 1989. Out of His Skin: The John Barnes Phenomenon. London: Faber and Faber.

Kay, Oliver. 2019. "Howard Gayle interview: I'm a fan but I was black before I was Liverpool." Times, March 11. Access 15 April 2019. https://www.thetimes.co.uk/article/howard-gayle-interview-im-a-fan-but-i-was-blackbefore-i-was-liverpool-gx93tgrgj

Liverpool City Council. 2016. "Ward profile: Princes Park.” Accessed 11 June 2018. https://liverpool.gov.uk/media/ 9961/princes-park.pdf

Lowe, Lisa. 2015. The Intimacies of Four Continents. Durham, NC: Duke University Press.

McKittrick, Katherine. 2002. “'Their blood is there, and they can’t throw it out': honouring black Canadian geographies.” Topia 7: 27-37.

Mignolo, Walter. 2011. "Epistemic disobedience and the decolonial option: a manifesto." Transmodernity: Journal of Peripheral Cultural Production of the Luso-Hispanic World 1 (2): 44-66. 
Mills, Charles. 1997. The Racial Contract. Ithaca, NY: Cornell University Press.

Moody, Jessica. 2014. "The memory of slavery in Liverpool in public discourse from the nineteenth century to the present day.” PhD diss., University of York.

Morgan, James. 2018. “Howard Gayle: Liverpool's Mo Salah has exposed hypocrisy of British attitudes towards Muslims.” Herald Scotland, May 20. Accessed 14 June 2018. http://www.heraldscotland.com/sport/16237578.Howard_Gayle_Liverpool_39_s_firs t_black_footballer_on_the_importance_of_Mo_Salah_to_British_Muslims/

Nayak, Anoop. 2010. "Race, affect, and emotion: young people, racism, and graffiti in the postcolonial English suburbs.” Environment and Planning A 42 (10): 2370-2392.

Ndhlovu, Finex. 2016. "A decolonial critique of diaspora identity theories and the notion of superdiversity.” Diaspora Studies 9 (1): 28-40.

Olusoga, David. 2016. Black and British: A Forgotten History. London: Macmillan.

Perraudin, Frances. 2017. "Liverpool student fights to remove Gladstone's name from building.” Guardian, November 16. Accessed 18 June 2018. https://www.theguardian.com/uk-news/2017/nov/16/liverpool-university-studentwilliam-gladstone-halls-of-residence

Quijano, Aníbal. 2007. “Coloniality and modernity/rationality.” Cultural Studies 21 (2-3): 16878.

Santos, Boaventura de Sousa. 2014. Epistemologies of the South: Justice against Epistemicide. London: Paradigm.

Savransky, Martin. 2017. “A decolonial imagination: sociology, anthropology and the politics of reality.” Sociology 51 (1): 11-26.

Schwarz, Bill. 2011. Memories of Empire, Volume 1: The White Man's World. Oxford: Oxford University Press.

Sharpe, Christina. 2016. In the Wake: On Blackness and Being. Durham, NC: Duke University Press.

Silverstein, Paul. 2004. Algeria in France: Transpolitics, Race, and Nation. Bloomington, IN: Indiana University Press.

Small, Stephen. 1991. "Racialised relations in Liverpool: a contemporary anomaly." New Community 17 (4): 511-537.

---- 2018. "Theorizing visibility and vulnerability in Black Europe and the African diaspora.” Ethnic and Racial Studies 41 (6): 1182-1197.

Steele, Murray. 2008. "Confronting a legacy: the Atlantic slave trade and the black community of Liverpool.” In Historical Perspectives on Social Identities, edited by Alyson Brown. Newcastle upon Tyne: Cambridge Scholars Publishing. 
Stoler, Ann Laura. 2016. Duress: Imperial Durabilities in Our Times. Durham, NC: Duke University Press.

Tafari, Levi. 1989. Liverpool Experience: Collected Poems. Neustadt: Michael Schwinn.

Thangaraj, Stanley. 2017. "Say her name! Confronting erasure and rethinking possibilities for a democratic future." Tropics of Meta, July 13. Accessed 18 June 2018. https://tropicsofmeta.com/2017/07/13/say-her-name-confronting-erasure-rethinkingpossibilities-for-a-democratic-future/

Through Paisley Eyes. 2018. "Ex Liverpool FC player Howard Gayle tells his story.” Accessed 15 April 2019. https://www.youtube.com/watch?v=Jbvd8AL09jY

Torpey, John. 2003. Politics and the Past: On Repairing Historical Injustices. Lanham, MD: Rowman and Littlefield.

Tuck, Eve and Yang, K. Wayne. 2012. “Decolonization is not a metaphor.” Decolonization: Indigeneity, Education and Society 1 (1): 1-40.

Turner, Robert. 2018. Not for Long: The Life and Career of the NFL Athlete. New York: Oxford University Press.

Uduku, Ola. 2003. "Ethnic minority perspectives.” In Reinventing the City? Liverpool in Comparative Perspective, edited by Ronaldo Munck. Liverpool: Liverpool University Press.

Upton, Dell. 2015. What Can and Can't be Said: Race, Uplift, and Monument Building in the Contemporary South. New Haven, CT: Yale University Press.

Yeğenoğlu, Meyda. 2017. "Cosmopolitan Europe: memory, apology and mourning." In European Cosmopolitanism: Colonial Histories and Postcolonial Societies, edited by Gurminder K. Bhambra and John Narayan. Abingdon: Routledge.

Zack-Williams, Alfred. 1997. “African diaspora conditioning: the case of Liverpool.” Journal of Black Studies 27 (4): 528-542.

Zeleza, Paul Tiyambe. 2005. "Rewriting the African diaspora: beyond the Black Atlantic." African Affairs 104 (414): 35-68. 